\title{
Bronchial gland histochemistry in lungs removed for cancer
}

\author{
W DE POITIERS, P W LORD, B BILES, AND W F WHIMSTER \\ From the Department of Morbid Anatomy, King's College Hospital, and MRC Toxicology Unit, \\ St Bartholomew's Hospital Medical College, London
}

ABSTRACT The bronchial glands in the main bronchus and succeeding generations of the inferior lingular airway have been studied in 10 left lungs removed surgically for lung cancer. The ratios of ${ }^{\circ}$ sulphated to sialidated mucin found did not coincide with previous results and suggested that this ${ }^{\circ}$

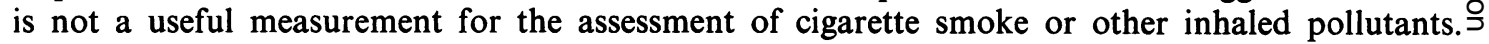
The total acid mucin, measured as a percentage of bronchial gland present, showed the same trends $\vec{c}$ as previously reported-namely, more storage of mucin in non-smokers and in more distal generations. The large dose of cigarettes smoked by the patients in the present series was reflected $\vec{\varphi}$ by a lower level of acid mucin storage, and this measure is potentially useful for assessing exposureo to cigarette smoke and other inhaled pollutants. The percentages of mucous and serous cells in. successive generations of an airway are recorded for the first time in these smokers and in a "normal" postmortem specimen. The results suggest that similar proportions of mucous and serous cells exist in both large and small airways, but with a tendency in the smokers for more mucous cells in the more distal generations.

The acid mucins synthesised by the cells of the bronchial glands may have sulphate (Su) groups on their side chains or sialic acid ( $\mathrm{Si}$ ) groups. Kollerstrom et $a l^{1}$ investigated the ratio of sulphated to sialidated mucin ( $\mathrm{Su} / \mathrm{Si}$ ratio) in each generation from the trachea down the inferior lingular bronchus in lungs taken at necropsy from smokers and non-smokers to see if the proportion of sulphated mucin decreased as had previously been suggested. ${ }^{2}$ They found this to be so and that the $\mathrm{Su} / \mathrm{Si}$ ratio was consistently higher in smokers. In the present study we repeated their investigation using 10 left lungs resected for lung cancer, because a full history could be obtained from the patients in the postoperative period and the tissue was much better preserved, in an attempt to see if their results for smokers were repeatable.

Kollerstrom et $a l^{3}$ also examined the proportion of acid mucin in the glands and found less acid mucin in the glands in the proximal generations and less in the smokers than in the non-smokers. We also repeated this examination in our cases and have compared the results.

In addition we took the opportunity to study

Address for reprint requests: Dr WF Whimster, Department of Morbid Anatomy, King's College Hospital, London SE5. the proportion of mucous to serous cells in each generation from the main bronchus down to the sixth generation along the inferior lingular. bronchus. This proportion has not previously. been studied along an airway.

\section{Methods}

Ten whole left lungs removed for lung cancer were studied. Details of each patient's medica 5 and occupational history were obtained routinely in the postoperative period (table 1).

On receipt, unfixed directly from the operating.

Table 1 Age, sex, and smoking habits of the 10 patients studied

\begin{tabular}{|c|c|c|c|}
\hline $\begin{array}{l}\text { Case } \\
\text { number }\end{array}$ & $\begin{array}{l}\text { Age } \\
(y r)\end{array}$ & Sex & Smoking history \\
\hline $\begin{array}{r}1 \\
2 \\
3 \\
4 \\
5 \\
6 \\
7 \\
8 \\
9 \\
10\end{array}$ & $\begin{array}{l}69 \\
67 \\
65 \\
67 \\
68 \\
51 \\
62 \\
53 \\
53 \\
57\end{array}$ & $\begin{array}{l}\mathbf{M} \\
\mathbf{F} \\
\mathbf{M} \\
\mathbf{M} \\
\mathbf{M} \\
\mathbf{M} \\
\mathbf{M} \\
\mathbf{M} \\
\mathbf{M} \\
\mathbf{M}\end{array}$ & $\begin{array}{l}1 \mathrm{oz} / \text { week } \\
\text { 30/day } \\
100 / \text { day } \\
60 / \text { day } \\
20 / \text { day } \\
0 \cdot 75 \mathrm{oz} / \text { day (pipe) } \\
4-5 \mathrm{oz} / \text { week } \\
30 / \text { day } \\
25 / \text { day } \\
20 / \text { day } \\
\text { Average } 34 \text { cigarettes/day }\end{array}$ \\
\hline
\end{tabular}


theatre, each lung was inflated with $10 \%$ formalin via the main bronchus until the pleura was fully distended. After fixation the bronchial resection margin was cut off for routine histology and then the main bronchus (generation 1), the upper lobe bronchus (generation 2), the lingular bronchus (generation 3), and the first three generations of the inferior lingular bronchus were dissected out unopened. From the main bronchus two longitudinal blocks of tissue about $10 \mathrm{~mm}$ long (including two or three cartilage rings) were taken from the cartilaginous part. Transverse rings were taken from the middle of each of the subsequent generations. In three cases-patients $5,6,8$-the carcinoma involved the upper lobe bronchus so these G2 blocks were omitted from the study. The routine examination of the lung and the tumour was then continued.

These bronchial blocks were taken, processed for histology, and cut to give five sets of serial sections, $500 \mu \mathrm{m}$ apart, for microscopic pointcounting of the bronchial glands in accordance with the rigorous procedure established by Lord et al. ${ }^{4}$ For the present study one section (HID/AB) from each set was stained with high iron diamine at $\mathrm{pH} 1.6$ for 18 hours (to stain sulphated mucin) and then with alcian blue at $\mathrm{pH} 2.6$ for 30 minutes (to stain sialidated mucin). Another section ( $\mathrm{AB} / \mathrm{H}$ and $\mathrm{E})$ from each set was stained for 30 minutes with alcian blue at $\mathrm{pH} 2.6$ (to stain all the acid mucin) and then counterstained with haematoxylin and eosin (to stain the rest of the glands).

Using the microscopic point-counting technique described by Lord et al, ${ }^{4}$ the following were recorded for each of the five levels through each block:

1 On the HID/AB stained slide, the points falling on the cells stained blue (sulphated mucin $(\mathrm{Su})$ ) and brown (sialidated mucin (Si)) were counted. These were expressed as the $\mathrm{Su} / \mathrm{Si}$ ratio.

2 On the $\mathrm{AB} / \mathrm{H}$ and $\mathrm{E}$ stained slide, the points falling on alcian blue stained gland and on gland not stained with alcian blue were counted. The points falling on alcian blue stained gland were expressed as a percentage of the total points falling on gland.

3 On the $\mathrm{AB} / \mathrm{H}$ and $\mathrm{E}$ stained slide, the points falling on mucous cells and on serous cells were recorded. The points falling on mucous cells were expressed as a percentage of the total points falling on mucous and serous cells. As we had no cases with which to compare the percentages of mucous cells, we examined the same airway from a previously healthy non-smoking 43 -year-old man from Derbyshire who died from an overdose of paracetamol and in whom the necropsy was carried out within four hours.

All the gland tissue on each section was point counted using a $0.5 \mathrm{~mm}$ squared eyepiece graticule. The appropriate objective was used to count at least 100 points although only in the most distal generations in some cases was this minimum approached.

For each case the arithmetic mean of each set of five results from each block was taken as the reading for each generation, except for the main bronchus (G1) in which the mean of the 10 readings from the two longitudinal blocks was taken as the reading. The means of the readings for all cases are shown as the series mean at each generation.

\section{Results}

Kollerstrom et $a^{1{ }^{3}}$ studied two groups of postmortem cases using bronchial generations along the inferior lingular pathway from G0 to G5 whereas we studied one group of surgically resected lungs using bronchial generations $\mathrm{G} 1$ to G6. For statistical comparisons only the $\mathrm{G} 1$ to G5 data were used.

\section{SULPHATED TO SIALIDATED (SU/SI) RATIO}

The $\mathrm{Su} / \mathrm{Si}$ ratios obtained for each of our cases at each generation are shown in fig 1 , with actual readings for Kollerstrom's groups of smokers and non-smokers and our group of smokers with lung cancer in table 2.

An analysis of variance of the logarithm of $\mathrm{Su} / \mathrm{Si}$, taking into account as factors the group type and linear regression on generation number, was carried out on all three groups of cases (table 3).

This analysis showed a significant variation among the cases in each group $(p<0.001)$ but not significant decreases in the $\log _{10}$ of $\mathrm{Su} / \mathrm{Si}$ with generation number. The gradient of the $\log _{10}$ of $\mathrm{Su} / \mathrm{Si}$ for Kollerstrom's smokers was $-0.061 \pm$ 0.01 (regression \pm SE). But there was no decrease in the $\log _{10}$ of $\mathrm{Su} / \mathrm{Si}$ with generation number for Kollerstrom's non-smokers and our smokers with lung cancer.

TOTAL MUCIN AS A PERCENTAGE OF TOTAL GLAND These percentages are shown for our cases in fig 2, with the readings at each generation for Kollerstrom's groups and our group in table 4. As for the $\mathrm{Su} / \mathrm{Si}$ ratios the percentage acid mucin results were tested by an analysis of variance (table 5) taking into account as factors smoking habits and linear regression on generation num- 


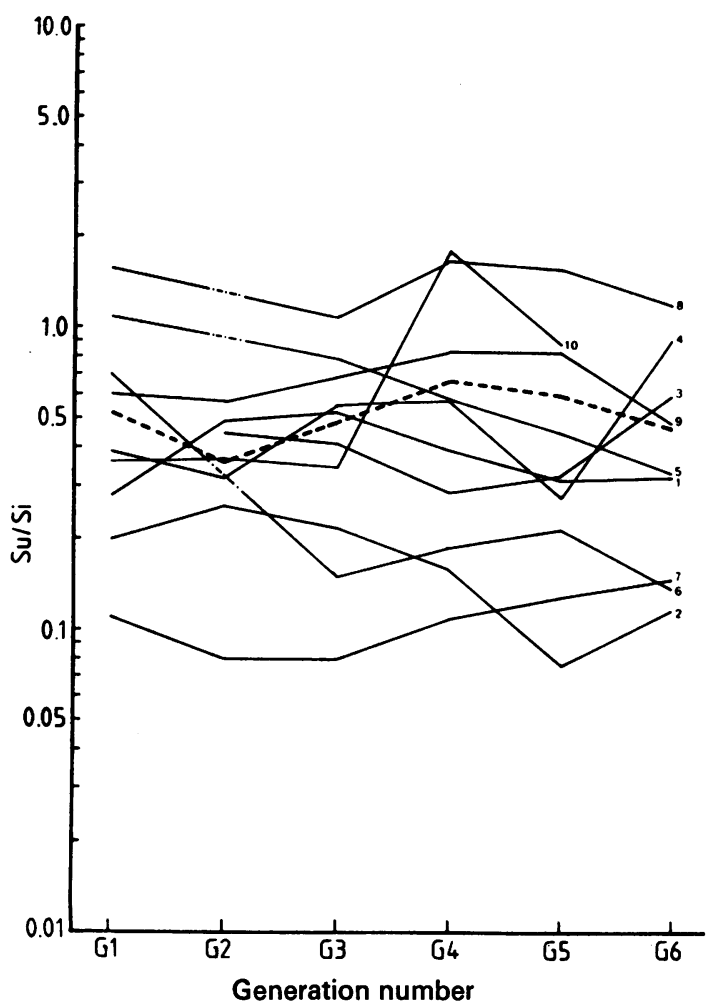

Fig $1 \mathrm{Su} / \mathrm{Si}$ values plotted logarithmically for smokers with lung cancer $(-)$ (mean values -- --) at each generation along the inferior lingular bronchial pathway. --_-- inticates that the value for the G2 bronchus is missing.

ber. This shows a significant variation among the three groups $(p<0.001)$. There is little difference between the means of the percentage acid mucin over all the generations (G1-G5) in
Table 3 Analysis of variance for $\log _{10}(\mathrm{Su} / \mathrm{Si})$ taking group and regression on generation number as factors

\begin{tabular}{|c|c|c|c|}
\hline Source of variation & $\begin{array}{l}\text { Degrees of } \\
\text { freedom }\end{array}$ & $\begin{array}{l}\text { Mean sum } \\
\text { of squares }\end{array}$ & $\begin{array}{l}\text { Variance } \\
\text { ratio }(F) \stackrel{\triangle}{\triangle}\end{array}$ \\
\hline $\begin{array}{l}\text { Group } \\
\text { Regression on generation number } \\
\text { Deviations from regression } \\
\text { Group x regression } \\
\text { Group x deviations from regression } \\
\text { Residual }\end{array}$ & $\begin{array}{r}2 \\
1 \\
3 \\
2 \\
6 \\
91\end{array}$ & $\begin{array}{l}1.024 \\
0.032 \\
0.023 \\
0 \cdot 114 \\
0.019 \\
0.082\end{array}$ & $\begin{array}{r}12.393 \\
0.391 \\
0.276 \\
1.382 \\
0.229\end{array}$ \\
\hline
\end{tabular}

Kollerstrom's smokers (mean $=63 \cdot 1 \%$ ) and nonis smokers (mean $=76.73 \%$ ) but our smokers with lung cancer showed a much lower value (mean ir $34.4 \%$ ) which was significantly different ( $p<$ है 0.001 ) from either of Kollerstrom's groups.

There is a significant regression on generation number for all the groups combined $(p<0.001$ 年 and the regressions are different for each group (table 6).

\section{MUCOUS CELLS AS A PERCENTAGE OF MUCOUS} AND SEROUS CELLS

Table 7 shows the mean percentage of mucous cells found at each generation for the 10 resected lungs and the normal lung. The percentages iri our 10 resected lungs (fig $3 a$ ) varied considerably but tended to increase down the airway and this was particularly marked in the woman (case 2$)$ In fig $3 b$ the series means (and standard errors from the lung cancer series are shown in relation to the single well-preserved "normal" post mortem case. It was not, of course, practicablè statistically to compare this single case with the group of 10 cancer cases.

Case 10 had anatomical variations in gener ation length which made the distal generations difficult to determine and the falls from G4 to

Table 2 Mean Su/Si values obtained from point counts at each generation for all cases in three groups. Omissions in the results indicate generations not used

\begin{tabular}{|c|c|c|c|c|c|c|c|c|c|c|c|c|c|c|c|}
\hline \multirow{3}{*}{$\begin{array}{l}\text { Case } \\
\text { number }\end{array}$} & \multicolumn{15}{|c|}{ Mean Su/Si values } \\
\hline & \multicolumn{3}{|c|}{ G1 } & \multicolumn{3}{|c|}{ G2 } & \multicolumn{3}{|c|}{$G 3$} & \multicolumn{3}{|c|}{$G 4$} & \multicolumn{3}{|c|}{ G5 } \\
\hline & $S$ & $N S$ & $\mathrm{Ca}$ & $S$ & $N S$ & $\mathrm{Ca}$ & $\boldsymbol{S}$ & $N S$ & $\mathrm{Ca}$ & $S$ & $N S$ & $\mathrm{Ca}$ & $\boldsymbol{S}$ & $N S$ & $\mathrm{Ca}$ \\
\hline $\begin{array}{c}1 \\
2 \\
3 \\
4 \\
5 \\
6 \\
7 \\
8 \\
9 \\
10 \\
\text { Series } \\
\text { mean } \\
\text { (士SE) }\end{array}$ & $\begin{array}{l}0.016 \\
0.657 \\
0.419 \\
0.606 \\
0.729 \\
0.520\end{array}$ & $\begin{array}{l}0.388 \\
0.191 \\
0.278 \\
0.279 \\
0.346 \\
0.179 \\
0.268\end{array}$ & $\begin{array}{l}0.280 \\
0.200 \\
0.390 \\
1.080 \\
0.070 \\
0.110 \\
1.570 \\
0.600 \\
0.360 \\
0.518 \\
(0.166)\end{array}$ & $\begin{array}{l}0.066 \\
0.570 \\
0.428 \\
0.687 \\
0.611 \\
0.484\end{array}$ & $\begin{array}{l}0.337 \\
0.201 \\
0.356 \\
0.352 \\
0.203\end{array}$ & $\begin{array}{l}0.490 \\
0.260 \\
0.450 \\
0.320 \\
\\
0.080 \\
0.570 \\
0.370 \\
0.363 \\
(0.062)\end{array}$ & $\begin{array}{l}0.446 \\
0.352 \\
0.952 \\
0.684 \\
0.434\end{array}$ & $\begin{array}{l}0.307 \\
0.332 \\
0.113 \\
0.297 \\
0.281 \\
0.185 \\
\\
0.253 \\
(0.103)\end{array}$ & $\begin{array}{l}0.530 \\
0.220 \\
0.420 \\
0.560 \\
0.800 \\
0.150 \\
0.080 \\
1.100 \\
0.690 \\
0.350 \\
0.490 \\
(0.100)\end{array}$ & $\begin{array}{l}0.424 \\
0.329 \\
0.292 \\
0.961 \\
0.525 \\
0.586\end{array}$ & $\begin{array}{l}0.310 \\
0.286 \\
0.412 \\
0.234 \\
0.254 \\
0.257 \\
0.290\end{array}$ & $\begin{array}{l}0.398 \\
0.160 \\
0.290 \\
0.580 \\
0.590 \\
0.190 \\
0.110 \\
0.700 \\
0.850 \\
0.840 \\
0.471 \\
(0.088)\end{array}$ & $\begin{array}{l}0.549 \\
0.244 \\
0.858 \\
0.442 \\
0.467\end{array}$ & $\begin{array}{l}0.201 \\
0.183 \\
0.266 \\
0.147 \\
0.187 \\
0.341 \\
0.196\end{array}$ & 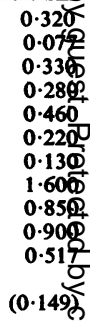 \\
\hline
\end{tabular}




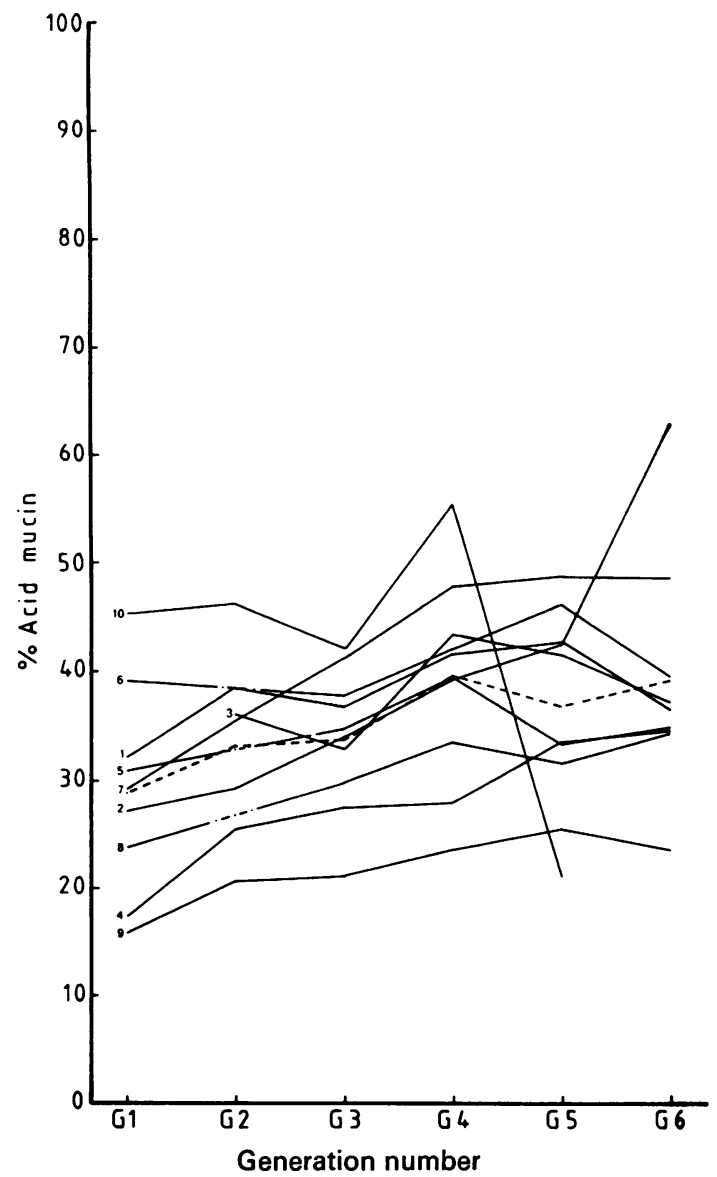

Fig 2 Acid mucin expressed as a percentage of total gland (-) (mean values - - -) in smokers with lung cancer. --_-- indicates that the value for the $\mathbf{G 2}$ bronchus is missing.
Table 5 Analysis of variance for percentage acid mucin taking group and regression on generation number as factors

\begin{tabular}{lcrrr}
\hline Source of variation & $\begin{array}{c}\text { Degrees of } \\
\text { freedom }\end{array}$ & $\begin{array}{r}\text { Mean sum } \\
\text { of squares }\end{array}$ & $\begin{array}{r}\text { Variance } \\
\text { ratio }(F)\end{array}$ \\
\hline Group & 2 & 16928.60 & 205.295 \\
Regression on generation number & 1 & 3954.44 & 47.956 \\
Deviations from regression & 3 & 163.50 & 1.983 \\
Group x regression & 2 & 600.94 & 7.288 \\
Group x deviations from regression & 6 & 40.35 & 0.489 \\
Residual & 78 & 82.46 & \\
\hline
\end{tabular}

Table 6 Group means and regression coefficients for percentage acid mucin

\begin{tabular}{llll}
\hline Group & $\begin{array}{l}\text { Number of } \\
\text { readings }\end{array}$ & $\begin{array}{l}\text { Mean } \\
\%\end{array}$ & $\begin{array}{l}\text { Regression coefficient } \\
( \pm S E)\end{array}$ \\
\hline Smokers & 25 & $63 \cdot 1$ & $8 \cdot 7 \pm 1 \cdot 30$ \\
Non-smokers & 25 & $76 \cdot 7$ & $5 \cdot 4 \pm 1 \cdot 05$ \\
Smokers with lung cancer & 50 & $34 \cdot 4$ & $2 \cdot 1 \pm 0.56$ \\
\hline
\end{tabular}

Table 7 Mean values of percentage mucous cells in gland at each generation for the series of 10 cases with lung cancer and the "normal" postmortem lung. Omissions indicate generations which were not used

\begin{tabular}{|c|c|c|c|c|c|c|}
\hline \multirow{2}{*}{$\begin{array}{l}\text { Case } \\
\text { number }\end{array}$} & \multicolumn{6}{|c|}{ Percentage mucous cells } \\
\hline & GI & $G 2$ & G3 & G4 & G5 & G6 \\
\hline $\begin{array}{l}1 \\
2 \\
3 \\
4 \\
5 \\
6 \\
7 \\
8 \\
9 \\
10 \\
\text { Series mean } \\
\text { (士SE) } \\
\text { "Normal" } \\
\text { postmortem } \\
\text { lung }\end{array}$ & $\begin{array}{l}36 \cdot 10 \\
39 \cdot 98 \\
25 \cdot 99 \\
50 \cdot 23 \\
59 \cdot 33 \\
49 \cdot 22 \\
39 \cdot 95 \\
26 \cdot 17 \\
74 \cdot 86 \\
44 \cdot 65 \\
(5 \cdot 25) \\
\\
58 \cdot 43\end{array}$ & $\begin{array}{l}61 \cdot 82 \\
35 \cdot 81 \\
76 \cdot 64 \\
51 \cdot 15 \\
(5 \cdot 34)\end{array}$ & $\begin{array}{l}48 \cdot 31 \\
43 \cdot 96 \\
50 \cdot 44 \\
47 \cdot 25 \\
60 \cdot 12 \\
68 \cdot 47 \\
66 \cdot 68 \\
49 \cdot 57 \\
39 \cdot 84 \\
70 \cdot 15 \\
54 \cdot 48 \\
(3 \cdot 46)\end{array}$ & $\begin{array}{l}53 \cdot 41 \\
51 \cdot 40 \\
61 \cdot 71 \\
41 \cdot 41 \\
59 \cdot 30 \\
62 \cdot 03 \\
74 \cdot 68 \\
46 \cdot 26 \\
36 \cdot 16 \\
77 \cdot 24 \\
56 \cdot 36 \\
(4 \cdot 23)\end{array}$ & $\begin{array}{l}54 \cdot 67 \\
57 \cdot 22 \\
57 \cdot 08 \\
44 \cdot 57 \\
52 \cdot 54 \\
64 \cdot 14 \\
76 \cdot 49 \\
45 \cdot 77 \\
41 \cdot 22 \\
24 \cdot 54 \\
51 \cdot 82 \\
(4 \cdot 44)\end{array}$ & $\begin{array}{l}44 \cdot 59 \\
73 \cdot 30 \\
50 \cdot 79 \\
50 \cdot 41 \\
51 \cdot 65 \\
61 \cdot 86 \\
70 \cdot 43 \\
47 \cdot 77 \\
34 \cdot 85\end{array}$ \\
\hline
\end{tabular}

Table 4 Mean percentage acid mucin values obtained from point counts at each generation for the three groups. Omissions in the results indicate generations not used

\begin{tabular}{|c|c|c|c|c|c|c|c|c|c|c|c|c|c|c|c|}
\hline \multirow{3}{*}{$\begin{array}{l}\text { Case } \\
\text { number }\end{array}$} & \multicolumn{15}{|c|}{ Mean $\%$ acid mucin values } \\
\hline & \multicolumn{3}{|c|}{$G 1$} & \multicolumn{3}{|c|}{$G 2$} & \multicolumn{3}{|c|}{ G3 } & \multicolumn{3}{|c|}{$G 4$} & \multicolumn{3}{|c|}{ G5 } \\
\hline & $S$ & $N S$ & $\mathrm{Ca}$ & $S$ & $N S$ & $\mathrm{Ca}$ & $S$ & $N S$ & $\mathrm{Ca}$ & $S$ & $N S$ & $\mathrm{Ca}$ & $S$ & $N S$ & $\mathrm{Ca}$ \\
\hline 1 & $47 \cdot 1$ & $76 \cdot 5$ & $32 \cdot 2$ & $35 \cdot 7$ & $78 \cdot 3$ & 38.5 & $77 \cdot 4$ & $81 \cdot 1$ & $36 \cdot 7$ & $73 \cdot 2$ & $83 \cdot 6$ & $41 \cdot 6$ & $89 \cdot 7$ & $79 \cdot 7$ & $42 \cdot 7$ \\
\hline 2 & $52 \cdot 3$ & $45 \cdot 1$ & $27 \cdot 1$ & $52 \cdot 4$ & $55 \cdot 6$ & $29 \cdot 3$ & 61.9 & $71 \cdot 1$ & $34 \cdot 1$ & $82 \cdot 8$ & $81 \cdot 4$ & $39 \cdot 3$ & $67 \cdot 3$ & $90 \cdot 5$ & 42.5 \\
\hline 3 & $42 \cdot 3$ & $70 \cdot 1$ & & $48 \cdot 5$ & $60 \cdot 4$ & 36.0 & $61 \cdot 6$ & & $32 \cdot 8$ & 74.5 & $92 \cdot 3$ & 43.5 & 69.9 & $85 \cdot 4$ & $41 \cdot 5$ \\
\hline 4 & $55 \cdot 8$ & 70.4 & $17 \cdot 4$ & 75.8 & 73.9 & $25 \cdot 5$ & & $84 \cdot 7$ & $27 \cdot 5$ & 88.4 & $82 \cdot 7$ & $27 \cdot 9$ & & $84 \cdot 3$ & 33.6 \\
\hline 5 & $27 \cdot 3$ & $69 \cdot 8$ & 30.8 & 58.5 & 74.8 & & $59 \cdot 1$ & $78 \cdot 7$ & $34 \cdot 7$ & $72 \cdot 5$ & $80 \cdot 5$ & $39 \cdot 5$ & $65 \cdot 4$ & $88 \cdot 1$ & $33 \cdot 4$ \\
\hline 6 & & & $39 \cdot 1$ & & & & & & $37 \cdot 8$ & & & $42 \cdot 1$ & & & $46 \cdot 2$ \\
\hline 7 & & & $28 \cdot 9$ & & & $35 \cdot 6$ & & & $41 \cdot 3$ & & & $47 \cdot 7$ & & & $48 \cdot 7$ \\
\hline 8 & & & $24 \cdot 0$ & & & & & & 29.8 & & & $33 \cdot 6$ & & & $31 \cdot 7$ \\
\hline 9 & & & $15 \cdot 7$ & & & $20 \cdot 7$ & & & $21 \cdot 1$ & & & $23 \cdot 6$ & & & 25.5 \\
\hline 10 & & & $45 \cdot 3$ & & & $46 \cdot 3$ & & & $42 \cdot 0$ & & & 55.4 & & & $21 \cdot 2$ \\
\hline Series & $45 \cdot 0$ & $66 \cdot 4$ & $28 \cdot 9$ & $54 \cdot 2$ & $68 \cdot 6$ & $33 \cdot 1$ & $65 \cdot 0$ & $79 \cdot 0$ & $33 \cdot 8$ & $78 \cdot 3$ & $84 \cdot 1$ & $39 \cdot 4$ & $73 \cdot 1$ & $85 \cdot 6$ & $36 \cdot 7$ \\
\hline$( \pm \mathrm{SE})$ & $(5 \cdot 0)$ & $(5 \cdot 5)$ & $(3 \cdot 2)$ & $(6 \cdot 6)$ & $(4 \cdot 5)$ & $(3 \cdot 3)$ & $(4 \cdot 2)$ & $(2.9)$ & $(2 \cdot 0)$ & $(3 \cdot 1)$ & $(2 \cdot 1)$ & $(2.9)$ & $(5 \cdot 6)$ & $(1 \cdot 8)$ & $(2 \cdot 9)$ \\
\hline
\end{tabular}

Categories as in table 2. 


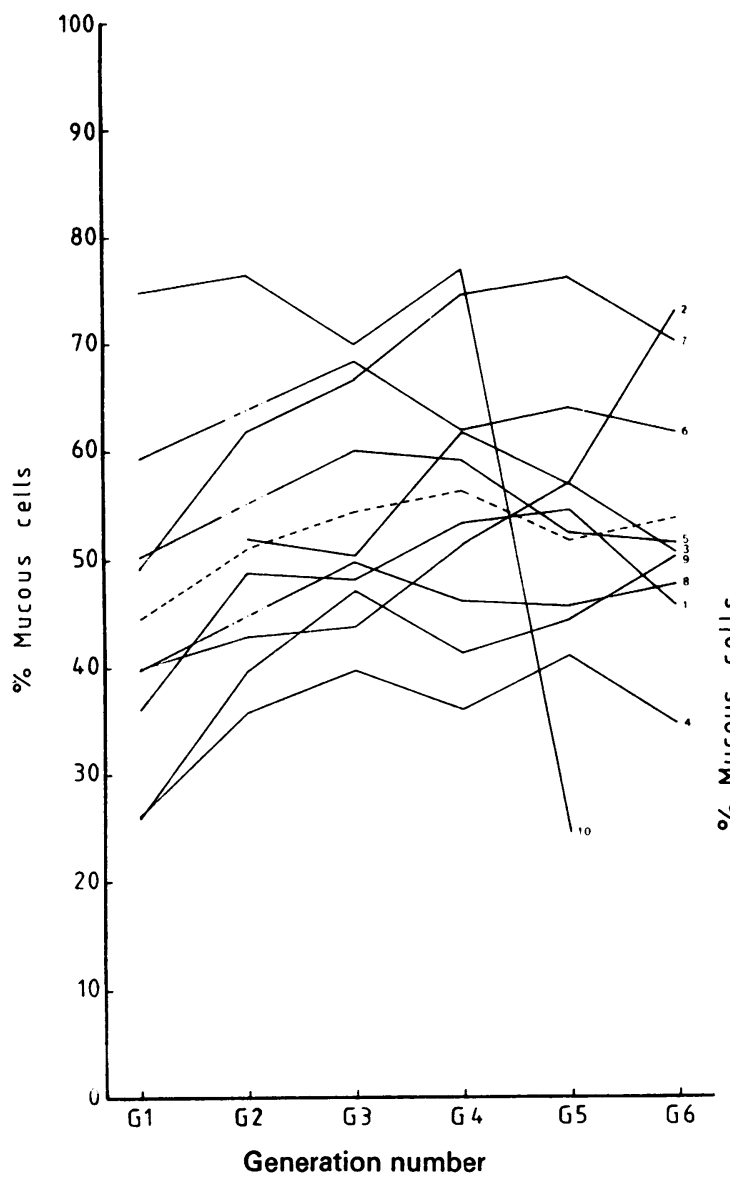

(a)

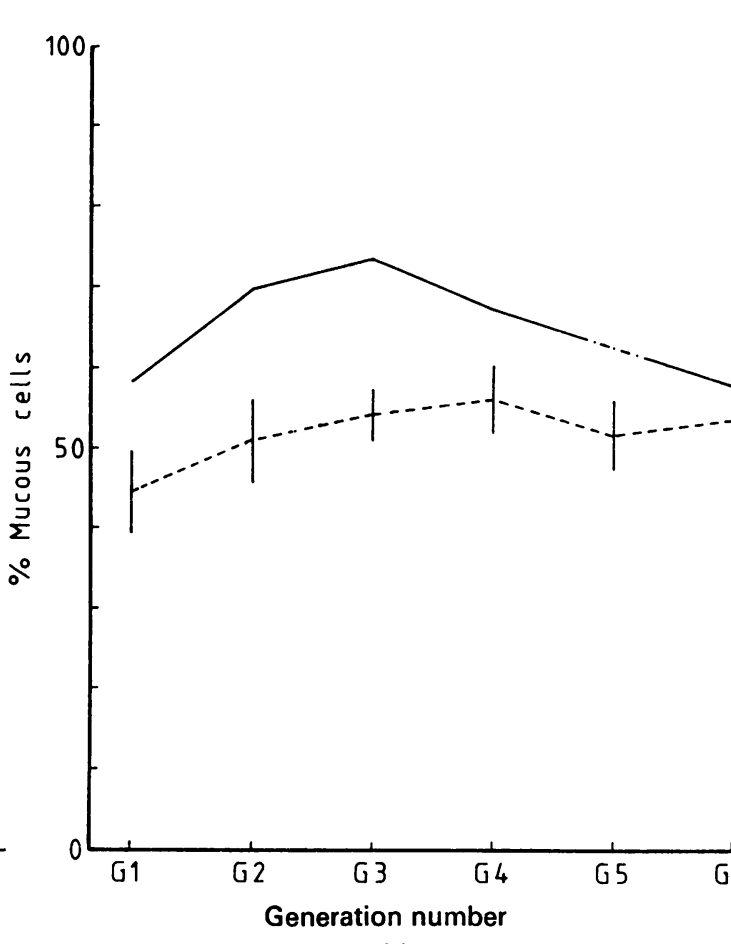

(b)

Fig 3 (a) Mucous cells expressed as a percentage of mucous and serous cells $(-)$ (series mean values - - -) in smokers with lung cancer. --_-- in 'icates that the value for the G2 bronchus is missing. (b) Mean values and standard errors from (a) (-- compared with the values obtained from one normal lung (-). - - - - indicates that the value for the G5 bronchus is missing.

G5 in figs 1, 2, and 3a were at variance with the other members of the series. Nevertheless, case 10 is included in each series mean.

\section{Discussion}

SULPHATED TO SIALIDATED (SU/SI) RATIOS Our present results (fig 1) were obtained by more rigorous sampling and counting on better preserved tissue than Kollerstrom et al ${ }^{1}$ found possible using postmortem material. Our results are within the general range established by these authors with means varying between 0.3 and 0.7 , and a range from 0.08 to 1.8 but without the downward trend shown by their smokers. In their paper Kollerstrom et $a^{1}$ did in fact establish a regression coefficient of $-0.032 \pm 0.009$ for their non-smokers and this trend can be attributed toos the inclusion of the G0 values. When the GO values for the non-smokers were excluded nou significant regression is found.

One might have expected our smokers, with an average consumption of 34 cigarettes per day to have had generally higher ratios than Kollers strom's smokers who smoked an average of 20 cigarettes per day. This was only so for $\mathbf{G 4}$ and5 G5, although one might expect these dista $\vec{D}$ generations to receive less cigarette smoke.

We conclude that after all the $\mathrm{Su} / \mathrm{Si}$ ratio is probably of little value as a marker of the bronchial gland response to cigarette smoke. 


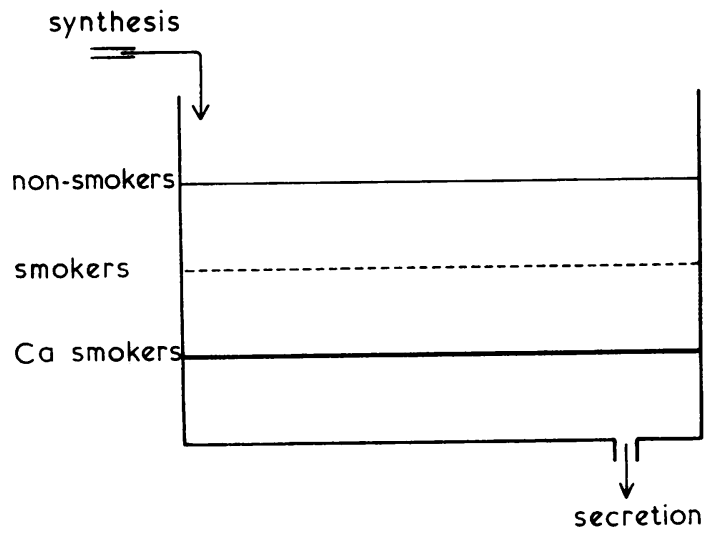

Fig 4 Diagrammatic representation of the differing equilibria between mucin synthesis and secretion established for non-smokers, smokers (20 cigarettes/day), and lung cancer patients (34 cigarettes/day).

TOTAL MUCIN AS A PERCENTAGE OF TOTAL GLAND This measure, again more rigorously produced, gave more compact results with more consistency within cases than Kollerstrom et $a^{3}$ found. The mean curve for our smokers (mean 34 cigarettes/ day) is significantly lower $(p<0.001)$ than those of Kollerstrom's smokers (mean 20 cigarettes/ day) and non-smokers and certainly falls where one might expect in relation to Kollerstrom's cases. The upward trend is similar although not as steep (table 6). These graphs do not, however, tell us anything about the rate of mucin synthesis or secretion. One can only say that the equilibrium between synthesis and secretion represented by the mucin retained within the cells (fig 4) is such that more mucin is stored in the cells of non-smokers than in smokers or smokers with lung cancer and that there is a tendency for more mucin to be stored in glands in distal generations. Measurements of mucin synthesis and secretion are unfortunately much more difficult to make and our measure of mucin storage remains a potentially useful way of discriminating between doses of cigarette smoke and possibly of other pollutants.

\section{MUCOUS CELlS AS A PERCENTAGe OF MUCOUS} AND SEROUS CELLS

We show the ranges for this measure down a bronchial pathway for the first time. Again the sampling and counting have been rigorously performed on well-preserved tissue. The standard errors (ranging from 3 to $5 \%$ ) are acceptble for biological material. It will, however, be difficult to establish the normal ranges in the UK because postmortems on non-smokers carried out quickly after death are rare. Nevertheless, it seems that the proportion of mucous and serous cells needed to produce the right mixture of secretions for the large proximal bronchi is much the same as for small bronchi. This is not to say that rates of synthesis or secretion of the mucous and serous cells are necessarily the same or, indeed, that these rates cannot vary independently. We therefore do not expect the proportions of mucous or serous cells to become a useful way of assessing inhaled pollutants. This measure is of more interest for studying why certain mixtures of mucous and serous cell secretions are found within the bronchi and how they are determined.

In conclusion, in our series of inferior lingular airways from lungs removed surgically for lung cancer we do not confirm the discriminatory value of the $\mathrm{Su} / \mathrm{Si}$ ratio; we support the potential value of the total mucin percentage measurement; and we provide preliminary results for the further study of the mucous cells and serous cells in the bronchial glands.

We are grateful to the Joint Research Committee, King's College Hospital, for financial support for this work.

\section{References}

1 Kollerstrom N, Lord PW, Whimster WF. A difference in the composition of bronchial mucus between smokers and non-smokers. Thorax 1977; 32:155-9.

2 Lev R, Spicer SS. A histochemical comparison of human epithelial mucins in normal and in hypersecretory states including pancreatic cystic fibrosis. Am J Pathol 1965; 46:23-47.

3 Kollerstrom N, Lord PW, Whimster WF. Distribution of acid mucus in the bronchial mucous glands. Thorax 1977; 32:160-2.

4 Lord PW, Biles BJ, Malinowska W, Whimster WF. A comparative study of the accuracy of area assessment by point counting for bronchial mucous glands. J Pathol 1978; 126:45-61. 